\title{
SUSTAINABILITY ASSESSMENT OF COASTAL DEVELOPMENT IN SOUTHERN REGION OF WEST JAVA PROVINCE, INDONESIA
}

\author{
Achmad RIZAL" \\ Universitas Padjadjaran, Faculty of Fisheries and Marine Science, \\ J1. Raya Jatinangor Km 21, Jatinangor, Sumedang 45363, West Java, Indonesia, e-mail: achmad.rizal@unpad.ac.id \\ Izza M. APRILIANI \\ Universitas Padjadjaran, Faculty of Fisheries and Marine Science, \\ Jl. Raya Jatinangor Km 21, Jatinangor, Sumedang 45363, West Java, Indonesia, e-mail: izza.mahdiana@unpad.ac.id \\ Rega PERMANA \\ Universitas Padjadjaran, Faculty of Fisheries and Marine Science, \\ Jl. Raya Jatinangor Km 21, Jatinangor, Sumedang 45363, West Java, Indonesia, e-mail: rega.permana@unpad.ac.id
}

\begin{abstract}
Citation: Rizal, A., Apriliani, I.M., \& Permana, R. (2020). SUSTAINABILITY ASSESSMENT OF COASTAL DEVELOPMENT IN SOUTHERN REGION OF WEST JAVA PROVINCE, INDONESIA. GeoJournal of Tourism and Geosites, 30(2spl), 808-817. https://doi.org/10.30892/gtg.302spl05-509
\end{abstract}

\begin{abstract}
Southern region of west Java province has a potential coastal geological outcrop archaic form of pre-tertiary to tertiary, believed to be the oldest rocks exposed on the surface. The region is planned to become a center growth area, that not only can provide economic benefits for regional development, but also protection for the sustainability of geological resources, and other surrounding natural resources. Using rap-sustainability dev methods, the paper descriptively investigates the sustainability status of the southern region of west Java includes the dimension of geology, ecology, economy, social, institutional and infrastructure/technology, as a basis for the development of the southern region of west java province. Furthermore, the paper outlines the multidimensional planning of the site, which is not only concentrated to the development in the field of coastal development alone, but also to develop various aspects, such as: biodiversity, geodiversity and culture diversity, including sites of ecological, archaeological, historical and cultural heritage, through conservation principles, and regional spatial planning, towards southern region of west java as a renowned tourist destination. This study contributes ideas, especially in incorporating socioeconomic and environmental variables in the southern region of west Java development.
\end{abstract}

Key words: southern region of west java, sustainability, rap-region, geological resource

\section{INTRODUCTION}

The southern region of West Java Province of Indonesia is the coastal area which consists of 5 districts namely Sukabumi district, Cianjur District, Garut District, Tasikmalaya District, and Pangandaran District. Legally, since the enactment of law 2/2015, the management of development in the southern part of West Java is completely in the hands of the West Java Provincial Government. Since Law 32/2009 was replaced by Law 2/2015 there has been modified in the holders of regional development authority from the district government to the provincial government authority. As a consequence of the management of the southern West Java region has indeed become a challenging and complex task for the provincial government (Rizal, 2018a; Rizal, 2018b). This zone has recently become quite popular in the development of tourism nationally. This zone refers to tourism which is focused on geology and natural landscape attraction. The southern region of West Java considers having five special characteristics, such as based on geological heritage, environmentally sustainable, informative, beneficial and tourist-satisfactory (Rizal, 2018a; Rizal et al., 2019). The southern region of West Java is a territory with welldefined limits that has a large enough surface area for it to serve several geological palaeontological heritage sites of special scientific importance rarity or beauty (Rizal, 2018a); it may not be sole of geological palaeontological significance, but also archaeological, ecological, historical or cultural value (Rizal and Lantun, 2017; Rizal, 2018a). The southern region of west Java has tremendously geological potential in the form of non-renewable resources that are rocks made of thousands of years of process, in a very beautiful structure in the region of five district. This region has a geological wealth in the form of old rock outcrops dating back from the Pre-Tertiary to Tertiary period, suspected to be the oldest rocks exposed on the surface (Rosana et al., 2006; Rizal, 2018a). The rock structure is an infinitely valuable natural resource that deserves developments as a historical asset of the nation. The value that is of concern is not only the monetary value in the market that can be obtained through the values of rock and mineral resources as well as other tradeable natural resources in the form of raw, processed, or even natural resources anyone can experience, through the environmental services of tourism activities, but also other intrinsic values inherent in the rock structure as one of the natural resources that cannot be detached from the historical formation process of the earth and also significant value to the education and the development of science (Rizal and Lantun, 2017; Rizal, 2018a). The natural resources in the southern region ofwest java have a uniqueness that is considered for the regional development, refers to the national development of Indonesia (Rizal, 2018a), which is that this area is an area that has resources of specific geological, mineral, geophysical, geomorphological, paleontological, or geographical features. This area also has important geological sites in terms of scientific quality, rarity, aesthetic values, and education. It is also possible that archaeological, ecological, historical, or cultural potentials swarm the area (Afroz et al., 2014; Rizal, 2018b).

Rizal (2018a) argued what drives a southern region of west java designation is not merely the "tremendous geological potential", but also the tourism interests, the political intentions and/or the social/academic organizations leading the process. Moreover, Center growth 
areas are exposed to criticisms such as the fact that they promote unsustainable tourism causing major problems to the geological/geomorphological assets they are allegedly protecting and/or that other protection devices seem to work better to promote protection. In this sense, the politics of regional development must follow sustainability (Armitage et al., 2015). But there is a widespread line of inquiry around the world which is proving that this is commonly a mere aspiration and that sustainability seems absent in many respects in various location (Boley and Nickerson, 2013; Aswita et al., 2018). Specific regional development needs to institutionalize the development of science-based specific regions or those with academic drafts with strong argumentations that cover the existing local conditions and circumstances which include the physical, social and economic conditions. It is the most important and main thing in the development of specific regions to institutionalize the sustainable specific regional development policies through the development of economic activities in alignment, such as tourism (Wunder, 2000; Daily et al., 2003; Khajeganet al., 2015; Chen et al., 2015; Rizal, 2018b).

The area development for the southern region of west java province to be a specific regional development for the purposes stated above, naturally requires a careful, focused as well as a science-based and adequate research planning that is in line with the development planning and scientific-based policies, as to how it should have been done in a variety of development sectors (De Stefano et al., 2014; Rizal, 2018a).

This paper discusses the sustainable ofsouthern of west java regional development model, its strategic dimensions in inclusive development, network and knowledge-based development reinforcement, and focus on the part of the development phase of the proposed southern region of west java, which concerns to the analysis of preparedness and prospects for the sustainability of specific regional development, using multi-dimensional rapid appraisal. The purpose of this research is to get the most suitable specific-area development model to the characteristics of the region, the natural resources potentials, the social capital (human resources), economical and sustainable feasibility. This study will be very useful as the access for planning the development of the southern region of west java province that can provide a significant economic impact for the coastal region and welfare of the people.

\section{METHODOLOGY}

This paper will outline the research in formulating a model of sustainable development of the southern region of west java province, by enclosing the considerations to the natural resources that exist through the justification process of the existing natural resources by resource mapping. This includes the carrying capacity analysis and environmental capacity, vulnerability analysis regarding disaster and economic valuation of natural resources both concerning the market and non-market values. Furthermore, this research also includes the consideration of public perceptions through social mapping (Duda and Hume, 2013; Rizal and Lantun, 2017; Rizal, 2018b; Rizal et al, 2019). Also, there are various scenarios for the development of non-conventional calculations of benefit-cost analysis to comprehend the value of regional development (Rizal et al., 2017). This sustainable development model will use a variety of analysis tools such as those described above by using resource mapping analysis, economic market and non-market valuation, social mapping, social perception analysis, Rap-region-dev (Rapid appraisal for Regional development), adapted from the RAPFISH model for a fisheries sustainability analysis Pitcher (1999), efficiency analysis (data envelopment analysis), B/C non-conventional analysis using economic valuation. In this paper, the authors will focus only on readiness analysis and rap-region-dev analysis. Rap-Region-Dev which is a developed model of Rapfish (rapid appraisal for Fisheries) previously developed by a team from the University of British Colombia and FAO (Pitcher, 1999; Pitcher and Preikshot, 2001; Pitcher et al., 2013). Fauzi and Anna (2002, 2005), states that RAP + MDS is a multi-disciplinary rapid appraisal to evaluate the comparative sustainability, based on a large number of easy-to-score attributes. In this study Region-Dev-RAP application is developed for the development of the southern region of west java, to analyze the sustainability of the southern region of west java development at the site. This Rap-Geo Dev analysis uses dimensions such as ecological, economic, social, institutional and infrastructure /technology.

\section{RESULTS DISCUSSIONS}

\section{Overview of Southern Region of West Java Province}

The southern region of west Java province covering 5 districts in this region (Figure 1). Geological diversity in this region includes seven groups of geological structures, namely: landforms, rock outcrops, unique shapes/exotic rocks, geological structures, sedimentary structures, fossils, sea cave, and waterfall. While the geological diversity itself consists of 26 types in form of sites (Rosana, 2015; Rizal, 2018a), among others mega-amphitheater; six waterfalls; white sand beaches (5districts); Geomorphology Sukabumi plateau; Morphology amphitheater and Pelabuhanratu bay; the oldest rocks of the small island; southern region of both region of Sukabumi District and Tasikmalaya District formation greywacke Sandstone-type location, that is the oldest sediment in West Java; Small Island, the location of Southern region of west Java province Formation monomik breccia type, also the oldest sediments in West Java; Mount Aseupan with the formations of the oldest of diorite intrusion rock formations, peridotite sites - serpentinite in the oldest form of the oldest ophiolite rocks (ultramafic) and metamorphic; Pillow lava (oceanic crust) and polimik breccia; Melange Complex-Nummulites fossils that are formed in a trough as the results of plate collisions. It contains components in the form of ophiolite rocks, metamorphic, sedimentary pelagic, limestone nummulite, pillow lavas and almost 5 districts of the southern region of west Java formation sediments; fence stone, rhino head stone, frog stone; dragon stone complex, batik stone, a form of unique southern region of West Java Province rock formations. The unique shapes are the results of the erosion and aberration process, resulting in a form of batik, dragon's spine, dragon's head, bulls, and the head of alien creature (ET) motifs. The other geological diversity in the area are ophiolite Mount Beas complex, is a complex of ophiolite rocks composed of peridotite dominance, as well as metamorphic rocks serpentine; metamorphic KeusikLuhur complex is a complex of metamorphic rocks consisting of greenschist and blueschist; Sodongparat Sea caves that are formed by an erosion and aberration process of the oldest rocks that consist of ophiolite complexes, mostly made of peridotite and amphibolite; Sodongparat ophiolite complex, which is a mantle, as the oldest rocks found in southern west Java province, consisting of ophiolite complexes dominated by peridotite, gabbro, and amphibolite as well as plagiogranite. There is also Cikepuh River estuary, the contact between gabbro and peridotite; Batu Belah (Tortoise Stone), that is the unique shaping as the result of erosion and aberration that creates the form of a tortoise, if it is closely looked at, it seems like the rocks were split, this is a tectonic contact between the peridotite rocks and mélange. There are also textured pillow lavas that are the type location of the oldest rocks in the form of Citerem basalt lava formations, and Citerem river estuaries as well as Citirem beach, coastal white sand beach where green turtles surface and lay eggs.

The biodiversity in the southern region of west Java province consists of three sites, namely: Sukabumi district Reservation (Cibanteng), Cikepuh Wildlife Sanctuary, and Pangumbahan Turtle Captive. The Cibanteng Reservation is a conservation area for endangered animals such as buffalo, leopards, and several rare plants. The Cikepuh Wildlife is a conservation area for endangered animals like buffalo and leopards, deer, snakes, rhinos, etc. A part of it isthe primary forest and rare plants, also mangrov e. Meanwhile, Pangumbahan is a conservation area/hatchery and breeding for green turtle (Rizal, 2018a). The southern region of west Java also has a rich cultural diversity, as onebatik center (CibendaVillage) and it is rich with local artistry as well. The Batik Center of Cibenda Village developsPakidulanbatik motif that is inspired by the beauty of nature of the southern region of west Java. 


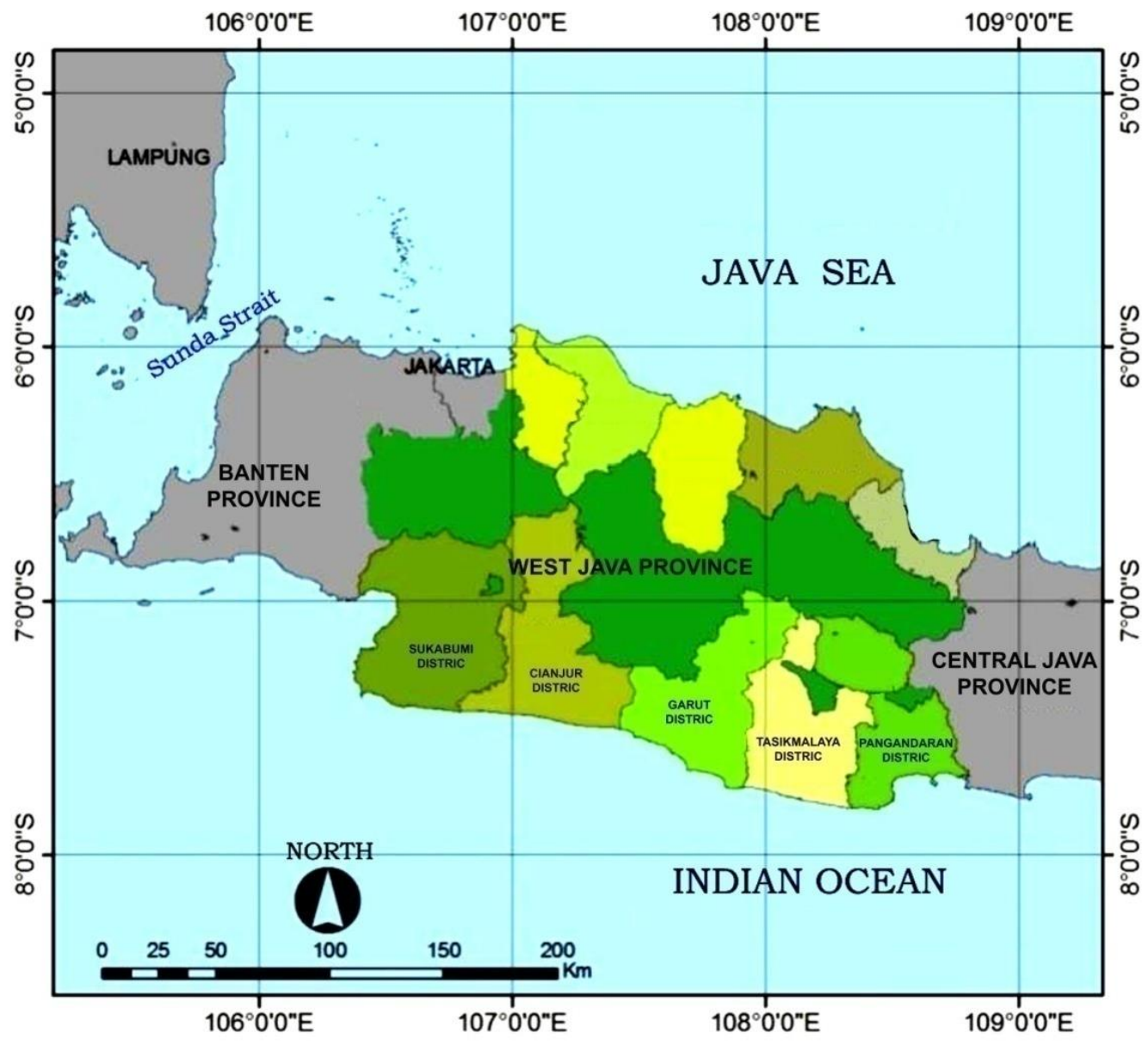

Figure 1. Map of research location (5 districts in southern region of west Java province)

\section{Regional Genetics Unit of Southern Region of West Java ProvinceAnalysis}

This research also conducted a genetics unit analysis of the southern region of west Java provincewithin the region, such as physical aspects that include water resources, geological disasters, community demographics, spatial of the area, and supporting infrastructure. The physical aspect of territoriality is then analyzed to obtain the carrying capacity and environmental capacity in regards to the development of research sites as a southern region of west Java. Based on the hydrogeologic cycle (Freeze, 1979) the water resources at the site consist of rainwater, river water, and groundwater. Each potential water resource is analyzed to obtain a picture of the quantity and quality there are in the sites. For rainwater resources for example, based on the Rainfall Map of Indonesia (Bakosurtanal, 2014), it is found that rainfall in the study site is somewhere between 3000-4500 mm/year, with the rain intensity of between 13.6 to $27.7 \mathrm{~mm} / \mathrm{day}$. As for the river water, based on the field conditions, there are two rivers, namelythe Cimarinjungriver and the Ciselang river, both flowing from north to south. Both rivers flow into southern region of west Java province river that flows from south to north. Meanwhile, in the southern part of the research siteisthe Cikarang River that flows from North to South. Based on the morphology of the research area, the location of the study consists of three (3) Watersheds, they are Cimarinjung, Ciletuh, and Cikarang. Additionally, based on the Groundwater Basin Map (Presidential Decree No. 26 of 2011), the majority of the research site (the north and center) is not a groundwater basin, while the southern part is a part ofthe JampangKulon Groundwater Basin (local groundwater basin within the district), with secure groundwater conservation zones. From theSukabumi Sheet Hydrogeology Map (Sutrisno, 1985), the potential aquifer of the research site consists of low localproductivityaquifer, medium local productivity aquifer, and medium aquifer productivity means that local low productivity aquifer occupies most of the research site and distributed in the north and center. The local medium productivity aquifer is located in the northwest and southwest parts of the site. Meanwhile, medium productivity aquifer occupies the southern part of the research site, where there is awater spring.

As for the analysis of geological hazard as one of the focus of the research needed for the development of the southern region of west Java, that is the potential ofthe southern region of west Java province covers the ground motion, earthquake, and the possibility of the tsunami. The results of the analysis of ground motion vulnerability maps of West Java (Department of Energy and Mineral Resources of West Java 2014), the southern region of west Java has a vulnerability level of very low, low, and medium. The very low vulnerabilitylevel occupies the northwest and south, the low vulnerability level occupies most of the research sites, and the medium vulnerability leveltakes place inthe north-central. Meanwhile, from the Disaster Prone Areas Map (Department of Energy and Mineral Resources of West Java 2014), the research location is considered an earthquake-safe area. As for a Tsunami potential, based on Tsunami Prone Areas Map in West Java (Department of Energy and Mineral Resources of West Java 2014), the distribution of areas prone to a tsunami is located in the westnorthwest-south in the research site, which consists of prone secure zones, medium prone zones, and highly prone zones.

The southern region of west Java province, in which the demographic review shows a population of as many as 9,617,195 people spread over 5 districts. The population of the southern region of west Java that consists of SukabumiDistrictis about 2,434,221 people, Cianjur District is about 2,335,121 people, Garut District is about 2,548,723 people, Tasikmalaya District is about 1,876,544 people, and in Pangandaran District is about 422,586 people (Central Statistics Bureau, 2018). Most of the residents in the area of research, work in the agricultural sector. The social problem that occurred in the development of this southern region of west Java province is the low education level, where the average population obtained their education up to primary school and junior high. Thus their understanding of the 
development of the southern region of west Java province is very minimum. The community is stuck on the idea of short-term profits, which why in the early development program, some of them conducted detrimental activities such as illegal mining, tourists extortion, and more in some areas. Based on the Spatial Planning of West Java (West Java Regional Regulation No. 22, 2010), the research site is divided into Forest Conservation, Suitable Forest Preserve, Watershed, Prone to Land Movement, Prone to Tsunami, Forest Reserve, Rice field, and Rural area. The condition of the existing land in the southern region of west Java province is in the form of shrubs, woods, estates, settlements, rain-fed farms, field/moor. In addition, there are several zoning regulations that apply to the research site, such as:

- Based on karst map of west Java (Regulations of West Java Governor No. 20/2006 on Regional Karst Protection of West Java), within the research site, there is a karst class 2 (two) area that is spread on the south part.

- Based on the Local Mining Map (Ministry of Energy and Mineral Resources No. 1204 K/30/MEM/2014 regarding Mining Zones in Java and Bali island), there are metal mining areas and Mineral areas, not metal and rock.

Further analysis of the supporting infrastructure of the southern region of west Java development, in regards to the delineation ofthe southern region of west Java (Department of Energy and Mineral Resources of West Java, 2017), shows that this location consists of coastal, plains and hills morphology/landscape with a height of between 0-500 m above sea level. Given the variety of morphology with the great difference in altitudes, in regards to Spatial Planning of West Java Province, the research site is divided into several functional path statuses, which include the status of district roads with their local primary function going up to $78,850 \mathrm{~m}$, district roads with a local secondary function going up to $1,500 \mathrm{~m}$, and rural roads withenvironmental primary functions going up to $9,000 \mathrm{~m}$.

The Sustainable Development Model of Southern Region of West Java

As explained previously, this paper suggests ideasfrom ongoing research on the sustainable and multidimensional development of the southern region of west Java, with the thinking basisof the model development as the Figure 2 below.

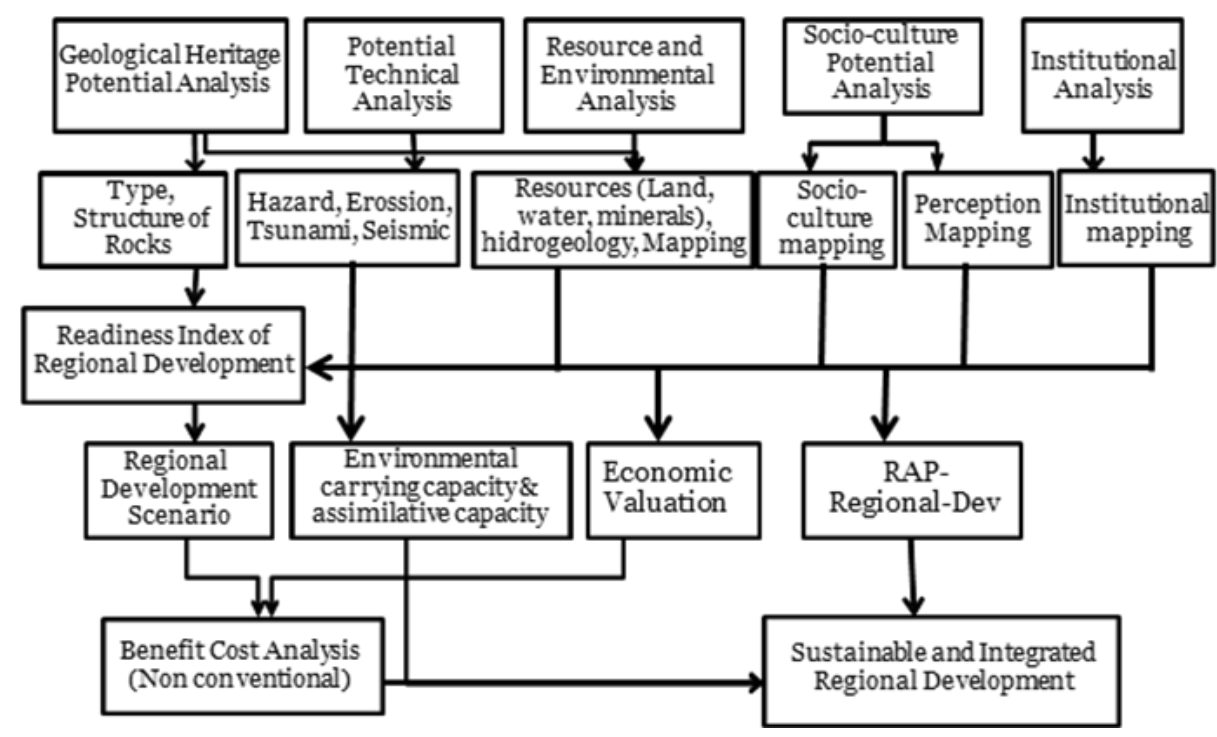

Figure 2. The Sustainable development model of the southern region of west Java

For the geological heritage analysis that includes the type and structure of the rocks, geological engineering that covers hazard, erosion, tsunami, hydrogeology analysis, and the potential of biological and cultural resources, has been previously described in the overview of the southern region of west Java. Meanwhile, the analysis of the social mapping is done by using a social mapping model that is developed from Participatory tools for micro-level poverty and social impact analysis (Woodley, 2002; Turner, 2006; World Bank, 2006; Palmer, 2012; UNWater, 2015; UN-General Assembly, 2015). This method is a method of visually showing the relative location of the households and the community distribution of variables such as women, men, adults, illiteracy, etc. together with the existing social structure.

This method is developed along with community mapping which is a visual method to identify and represent the perceptions of key institutions, both formal and non-formal. The development is also conducted through the analysis of public perceptions (Pahl-Wostl et al., 2013; Mekonnen and Hoekstra, 2016) regarding the development of the southern region of west Java that is also a visual method to identify and represent the perceptions of key institutions in regardsto region development, both formal and informal as well as individual and their relationships and importance of different social groups. The entire mapping is important for the understanding of social relationships that mediate the transmission of policy changes, which, in this regard, is the development of the southern region of west Java. The preliminary analysis shows a relatively homogeneous type of society in the southern region of west Java that covers 5 districts that are looked at, where farmers and fishers make the most of the community. Based on the questionnaire to 500 respondents in the southern region of west Java location, in general (100\%) they agree and support the development of the southern region of west Java in their area, although there is a small portion (12\%) that shows fear of social change, while another $9 \%$ worries about losing their livelihood as mineral miners, and farmers, while the rest has no concern whatsoever. The concerns for social changes in people's behavior have begun to show in the form of a handful of people who started taking advantage by doing negative things, such as extortion from road renovation, mining rocks around the area, littering, and so forth. The institutions involved in the development of this southern region of west Java are of the government, private, academia, and the public. The type of engagement is in line with the evolution that underwent a process of innovation from beinginward-looking in a sealed system toa more collaborative and focused to the outward, to the point that it becomes a more ecosystem-centric performed together cross-institutions. Lindegard (2010) and Lave (2012) stated that open innovation is combining internal and external resources and activating the opportunity to make it happen.

Open Innovation is a new paradigm that is rooted in the Quadruple Helix model, where government, industry, academia, and the community work together to create the future and drivethe structural changes far beyond the capability ofan organization itself or an individual. With this type of collaboration, it is expected that the southern region of west Java development will be optimum. 
The development of the southern region of west Java, as shown in Figure 3, carried out by the government together with the tourism industry that has begun to invest in the region, academia and research institutes are intensely researching as the basis of policymaking in the research development. The role of the private sector that actually has nothing to do with the tourism direct investment, but isconcerned aboutdeveloping the community empowerment in the vicinity of the southern region of west Java area plays an important role in changing social behavior and culture of the people and to improve their capacity in the familyeconomics, through Community Social Responsibility (CSR) program. The abundant geological resources and other ecological resources become what is enjoyed by the entire supply chain from the industrial production inputs to society, farmers, fishermen, and fish farmers, to the processing industries, and finally to the consumer. Everything is in order to obtain a common goal to have the optimum quality and productivity, innovation ability, acquire consumer response, the productsof the community, as well as from the tourism industry, also the security and reliability.

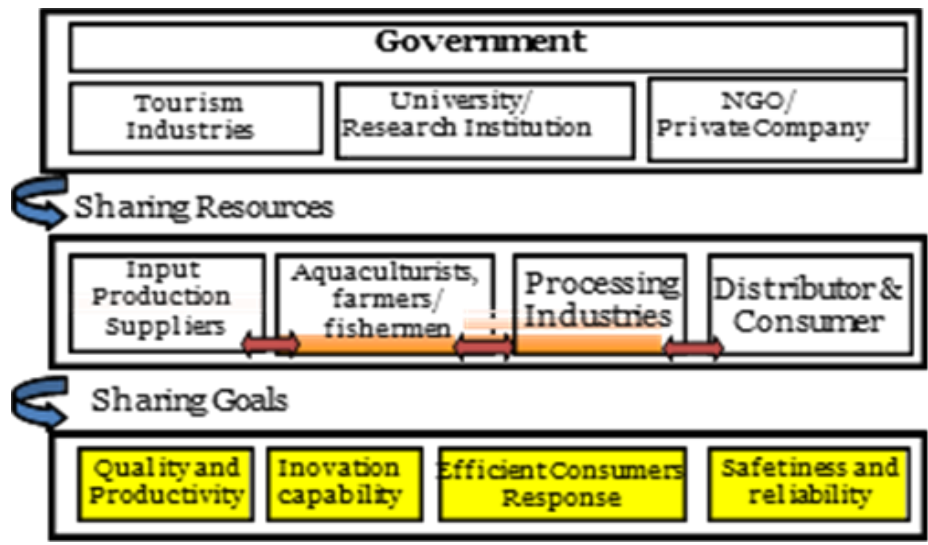

Figure 1 - Strategic Dimensions of Southern Region of West Java Development in an Inclusive Development

(Source: An adaptation from Wilk and Fensterseifer, 2003)

The role of network research in the development of the southern region of west Java tourism industry is shown in the Figure 4 below. The supporting and institutional sectors' functions are in line with the supporting function of natural resources and the environment which is the management basisin the resource-based economy.

Kodir (2018) argue that reinforced networkis the impact of reinforcing the social capital and human capital capacity for both academics and researchers by knowledge-based reinforcementto understand the natural resources that, in this case, are geological and non-rheological resources, that will optimizethe access for markets and knowledge as well as the infrastructure and institutions. By boosting programs like market empowerment, empowerment of institutions, social empowerment, and financial empowerment, it is expected that the development of this Region can compete and provide an opportunity for the community's economic development.

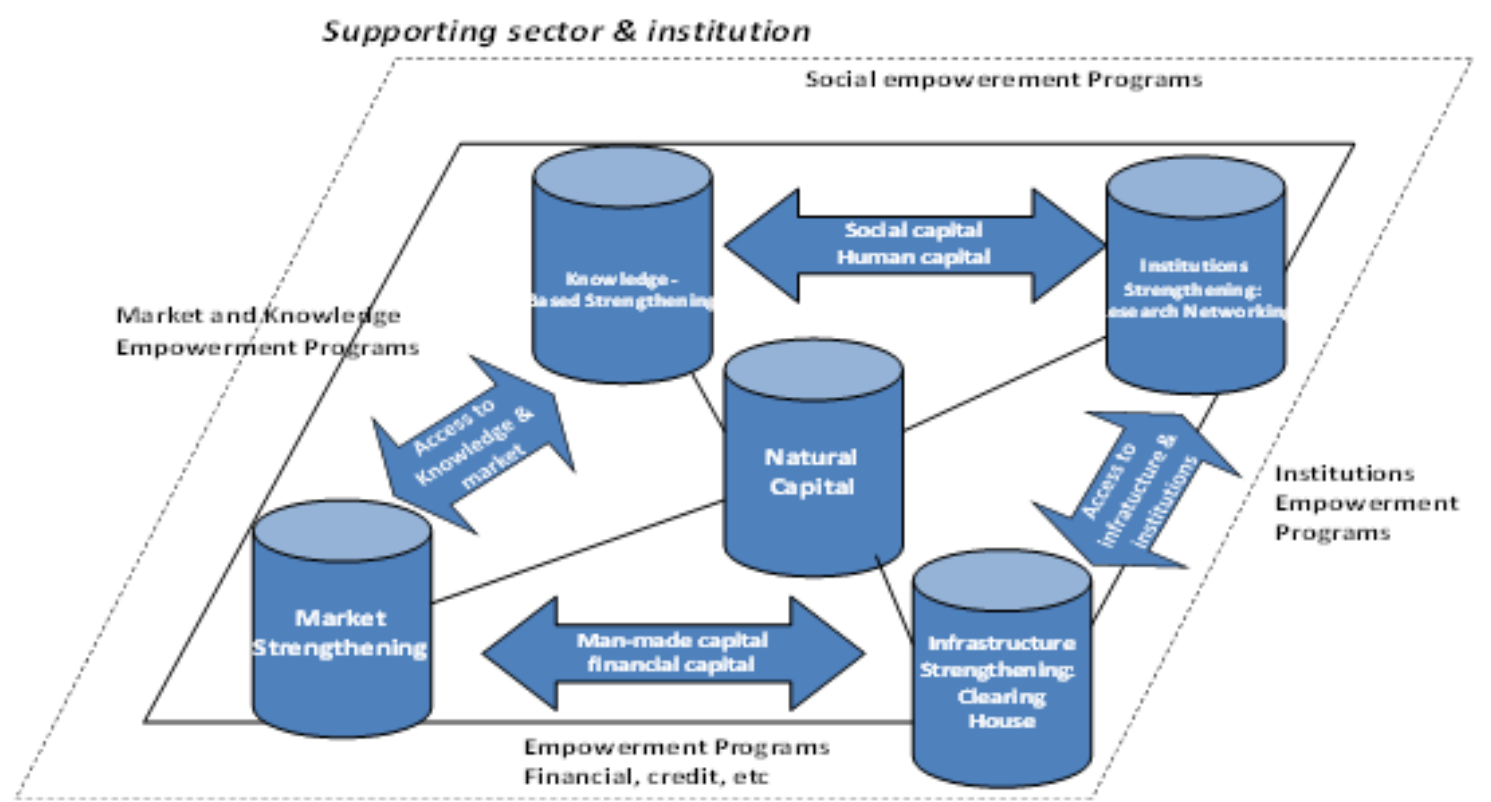

Supporting resources \& environment

Figure 2 - Network, and knowledge-based southern region of west Java development reinforcement

The readiness of the investment analysis is measured from the readiness of the entire networks of the institutions, communities, and the results fromacademia, and other researchers who give a green light for the tourism development in the region. Thus, the variables that are used as readiness analysis indicatorsare conducted qualitatively as shown in the table below.

As shown in the table 1 below, the readiness variables of basic information for the development ofthe southern region of west Java are still incomplete, and some of them are still in ongoing researches or no information at all. The complete information is related tothe geology heritage conditions, which has been widely studied by geology experts (Rosana et al., 2006), the information in regards to the ecological and cultural heritage are there and adequate (Franks and Cleaver, 2007; Hakim and Soemarno, 2017). 
Table 1. Readiness analysis on southern region of west Java development

\begin{tabular}{|c|c|c|c|c|c|}
\hline \multirow{2}{*}{ Variable in and under develop for southern region of west Java Development } & \multicolumn{5}{|c|}{ Readdiness } \\
\hline & Yes & No & On going Research & Develop & Possibly happend \\
\hline $\begin{array}{l}\text { Back ground Information: } \\
\text { - Define boundaries } \\
\text { - Define potential geological heritage } \\
\text { - Define potential geological structures/technique } \\
\text { - Hazzard } \\
\text { - Potential geological services } \\
\text { - Potential other natural resources/environmental services } \\
\text { - Potential ecological heritage } \\
\text { - Potential cultural heritage } \\
\text { - Carrying capacity and Assimilative Capacity } \\
\text { - Infrastructure need } \\
\text { - Economic valuation }\end{array}$ & $\begin{array}{l}\text { V } \\
\text { V } \\
\text { V } \\
\text { V }\end{array}$ & V & V & $\begin{array}{l}\text { V } \\
V\end{array}$ & \\
\hline $\begin{array}{l}\text { Potential Stakeholders } \\
\text { - Communities } \\
\text { - Government } \\
\text { - Investors } \\
\text { - NGO } \\
\text { - Private Sectors } \\
\text { - Potential tourists } \\
\end{array}$ & $\begin{array}{l}\mathrm{V} \\
\mathrm{V} \\
\mathrm{V} \\
\mathrm{V} \\
\mathrm{V} \\
\mathrm{V}\end{array}$ & & & & \\
\hline $\begin{array}{l}\text { Institutional Supports: } \\
\text { - Local regulatory } \\
\text { - Framework development } \\
\text { - Planning development } \\
\text { - Additional regulation laws/administrative rules } \\
\text { - Define land tenure/property right } \\
\text { - Local government support } \\
\text { - Central government support } \\
\text { - Local organization support } \\
\text { - Global organization support } \\
\text { - Local Community support }\end{array}$ & V & $\begin{array}{l}\text { V } \\
\text { V }\end{array}$ & $\begin{array}{l}\text { V } \\
\text { V } \\
\text { V } \\
\text { V } \\
\text { V }\end{array}$ & & \\
\hline $\begin{array}{l}\text { Socio-Economic-Environmental Impact: } \\
\text { - Loss of livelihoods and income } \\
\text { - due to restricted land uses or natural resources extraction } \\
\text { - Reduced food security due to loss access to natural resource based food } \\
\text { - Increase land prices resulting from increased demand for land } \\
\text { - Increase employment/change in profession/job } \\
\text { - Poverty reduction } \\
\text { - Moral hazard } \\
\text { - Environmental damage }\end{array}$ & $\begin{array}{l}\mathrm{V} \\
\mathrm{V} \\
\mathrm{V} \\
\mathrm{V} \\
\mathrm{V}\end{array}$ & $\mathrm{V}$ & $\begin{array}{l}\mathrm{V} \\
\mathrm{V}\end{array}$ & & \\
\hline
\end{tabular}

There are potential stakeholders and they are all adequate for the basic capital southern region of west Java development, while the institutional support is still very inadequate with the recent local regulatory, local government, and local community support. This condition is not sufficient for the development of the region. In the analysis of the socio-economic and environmental impacts, from the existing conditions, it appears that since the implementation of conservation areas and the prohibition of mineral mining in this regiondecreased the income of the community. However, after the long-term, the decline in poverty is expected to take effectaligned with the economic growth with the increased of the people'scapacity to start the business. This scenario only will happen if there is a combination of environmental responsibility with the generation of local economic benefits that will have both a development impact and serve as conservation incentives (Wunder, 2000; Dominick et al., 2012). Nevertheless, the chance of moral hazard has been appearingin the existing condition, where there is extortion of tourists, damaging the roads, and more. There are also environmental damages, particularlyforest trespassing andillegal mineral mining. The sustainability analysis using Rap-region-dev, using five dimensions, which have its own attributes, with thescoring scheme definition being good and bad and ranging from 0 to 3, as shown in Table 2 below.

RAP-Region-Dev analysis is performed on represented by 9 sub-districts in 5 districts located, to analyze the sustainability of the southern region of west Java development based on the 5 dimensions above. These subdistricts are Ciracap and Palabuhanratu (of Sukabumi district), Sindangbarang and Cidaun (of Cianjur district), Pameungpeuk and Cibalong (of Garut district), Cipatujah (of Tasikmalaya district), and Parigi (of Pangandaran district). This study using the mostly collected primary data and partly secondary, the results obtained are inthe form ofa kite diagram of sustainability analysis as follows (Figure 5). From the Figure 5 appears that some of the dimensions in each district that is analyzed are at anaverage value closer to the axis of the diagram, showing medium sustainability, only the ecological and geological dimensions that demonstrate high sustainability valuefrom most of these subdistricts at above 50\%, even for the two subdistricts, namely Sindangbarang and Cidaun scored the sustainability values above $80 \%$. The highest economic sustainability value comes from the PalabuhanRatu subdistrict that is indeed the central subdistrict for tourism in the region. The geology dimension has a moderate sustainability value due to highly hazardous factor in most of the region, especially in a tectonic earthquake, because the area is a part the active collision area between the Indian Ocean and Australian plates, therefore it needs to be managed in the development of this area as the prevention and mitigation of disasters. This includes the development of a green belt to mitigate tsunami, massive reforestation, and the prevention of illegal logging in the upstream area, and so forth. The overall results of per dimension analysis in the southern region of west Java are in the diagram below. From the bar chart below appears that in the geology dimension, the most sensitive attributes to the sustainability of the development of the southern region of west Java at the study site are thetectonic earthquake, as well as the hazard that is related to erosion. Both show low impact evidence level, but if any of them occurred, then the sustainability of the region area development would be the most disrupted. It is actually confirmed with the location of the southern region of west Java which is in the tectonic belt. 
Table 2. Dimension, attribute, scheme definitionand scoring of Rap-Region-Dev

\begin{tabular}{|c|c|c|c|c|}
\hline \multirow{2}{*}{ Dimension } & \multirow{2}{*}{ Attribute } & \multirow{2}{*}{$\begin{array}{l}\text { Scheme definition } \\
\text { Scoring }\end{array}$} & \multicolumn{2}{|c|}{ Scoring } \\
\hline & & & Good & $\mathrm{Bad}$ \\
\hline Geology & $\begin{array}{l}\text { Geological heritage diversity } \\
\text { Geological hazard: } \\
\text { Tsunami } \\
\text { Erossion } \\
\text { Volcano } \\
\text { Land slide }\end{array}$ & $\begin{array}{l}>10=\text { very good }(3) . \text { good } 9-7(2), \text { fair } 6-4(1),<4=\text { bad }(0) . \\
\text { No evidence: } 0 \text {, Probability happend }=1 \\
\text { Evidence small impact }=2 \text {, evidence high impact=3 } \\
\text { No evidence: } 0 \text {, Probability happend }=1 \\
\text { Evidence small impact=2, evidence high impact }=3 \\
\text { No evidence: } 0 \text {, Probability happend }=1 \\
\text { Evidence small impact=2, evidence high impact }=3 \\
\text { No evidence: } 0 \text {, Probability happend }=1 \\
\text { Evidence small impact }=2 \text {, evidence high impact=3 }\end{array}$ & $\begin{array}{l}3 \\
0 \\
0 \\
0 \\
0\end{array}$ & 3 \\
\hline Ecology & $\begin{array}{l}\text { Biodiversity } \\
\text { Raw Water Quality } \\
\text { Geographic Proximity to water sources } \\
\text { Catchment area }\end{array}$ & $\begin{array}{l}>100 \text { good }=3,99-50 \text { fair }=2,49-20 \text { average }=1,<20 \text { Bad=0 } \\
\text { Based on Water Classification }(\mathrm{PP} 82 / 2001) \text {. Class } 1=\text { Raw drinking } \\
\text { water }(3) \text {, class } 2=\text { for cultivation/recreation }=(2) ; \text { class } 3=\text { for fish } \\
\text { cultivation, farming }=(1) \text {, class } 4=\text { for plants, others }=0 . \\
\text { Near }=2 \text {, Medium }=1 \text {, Far }=0 \\
>75 \% \text { of good land = } 3 \\
50-75=\text { adequate }=2 \\
25-50=\text { not good }=1 \\
0-25=\text { bad }=0\end{array}$ & $\begin{array}{l}3 \\
3\end{array}$ & $\begin{array}{l}0 \\
0\end{array}$ \\
\hline Economy & $\begin{array}{l}\text { WTP of the community to the southern region } \\
\text { of west Java } \\
\text { Purchasing capability/Income } \\
\text { Poverty } \\
\text { Job diversity }\end{array}$ & $\begin{array}{l}\text { Far above average income }=\text { good }(2), \text { Within the range of average } \\
\text { income }=\text { fair }(1) \text {, below average income }=\text { bad }(0) \\
\text { Above the local minimum wage }=\text { good } 2 \text {, local minimum wage=fair } 1 \text {, } \\
\text { below the local minimum wage }=\text { bad } 0 \\
\text { high: } 75-100 \%=3 \text {, rather high: } 76-50 \%=2 \text {, medium: } 51-25 \%=1 \text {, low: } \\
26-0 \%=0 \\
\text { High: } .>20=2 \text {, medium } 19-10=1, \text { low }<9=0\end{array}$ & $\begin{array}{l}2 \\
2 \\
0 \\
2\end{array}$ & $\begin{array}{l}0 \\
3\end{array}$ \\
\hline Social & $\begin{array}{l}\text { Traditional wisdom in regards of resources and } \\
\text { southern region of west Java } \\
\text { Teamwork in resources and southern region of } \\
\text { west Java management (co-management) } \\
\text { Utilization of natural resources and southern } \\
\text { region of west Java conflict status } \\
\text { The role of CSR in the resources management } \\
\text { and community's capacity building } \\
\text { Crime rate } \\
\text { Moral hazzard }\end{array}$ & $\begin{array}{l}\text { High: } 2 \text {; Medium: } 1 \text {, Low: } 0 \\
\text { Yes }=2 \text {, On progress }=1 ; \text { none }=0 \\
\text { High }(\text { More than } 5 \text { conflicts a year })=2 ; \text { medium }(2-5 \text { conflicts a } \\
\text { year })=1 ;(0-1 \text { conflict a year })=0 \\
\text { Present, proper }=2 ; \text { Present not proper }=1 ; \text { Not present }=0 \\
\text { High }(>10 \text { cases } / \text { month })=3 \text {, medium }(9-5 \text { cases } / \text { month })=2 \text {, Low }(4-1 \\
\text { cases } / \text { month })=1 \text { none }(0 \text { case } / \text { month })=0 \\
\text { High: } 2 ; \text { Medium: } 1 \text {, Low: } 0\end{array}$ & $\begin{array}{l}2 \\
2 \\
0 \\
0 \\
0 \\
0\end{array}$ & $\begin{array}{l}0 \\
3\end{array}$ \\
\hline Institution & $\begin{array}{l}\text { Public Institution of southern region of west Java } \\
\text { Governance } \\
\text { Government's aid in managing the area } \\
\text { Area management planning } \\
\text { District budget allocation for area conservation }\end{array}$ & $\begin{array}{l}\text { Proper }=3 ; \text { Medium }=2 ; \text { Idle }=1 ; \text { None }=0 \\
\text { Proper }=2 ; \text { Less proper }=1 ; \text { None }=0 \\
\text { Proper }=2 ; \text { Less proper }=1 ; \text { None }=0 \\
\text { Proper }=2 ; \text { Less proper }=1 ; \text { None }=0 \\
\text { Proper }=2 ; \text { Less proper }=1 ; \text { none }=0\end{array}$ & $\begin{array}{l}3 \\
2 \\
2 \\
2 \\
2\end{array}$ & $\begin{array}{l}0 \\
0 \\
0 \\
0 \\
0\end{array}$ \\
\hline $\begin{array}{l}\text { Infrastructure } \\
\text { / Technology }\end{array}$ & $\begin{array}{l}\text { Raw water provider infrastructure } \\
\text { Provincial roads infrastructure } \\
\text { District roads infrastructure } \\
\text { Sub-district/village roads infrastructure } \\
\text { Internet connection } \\
\text { Hotel/lodging }\end{array}$ & $\begin{array}{l}\text { Available, running well }=3 ; \text { Not available, not running well }=2 ; \\
\text { Available butidle because not economically }=1 ; \text { not available }=0 \\
\text { Available proper }=2 ; \\
\text { Available not proper }=1 ; \text { Not available }=0 \\
\text { Available, proper }=2 ; \\
\text { Available not proper }=1 ; \text { Not available }=0 \\
\text { Available, proper }=2 ; \\
\text { Available not proper }=1 ; \text { Not available }=0 \\
\text { Available, proper }=2 ; \\
\text { Available not proper }=1 ; \text { Not available }=0 \\
\text { Available, proper }=2 ; \\
\text { Available not proper }=1 ; \text { Not available }=0\end{array}$ & $\begin{array}{l}3 \\
2 \\
2 \\
2 \\
2 \\
2 \\
2\end{array}$ & 0 \\
\hline
\end{tabular}

\section{GEOLOGY}

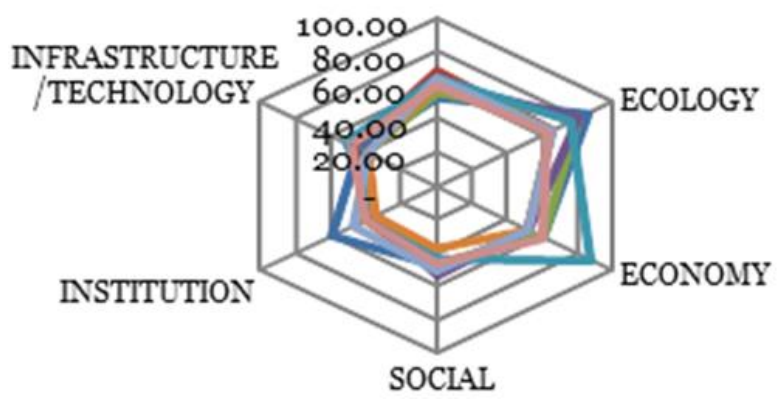

Palabuhanratu

Ciracap

Sindangbarang

Cidaun

Pameungpeuk

Cibalong

Cipatujah

Parigi

Figure 5. Kite Diagram Analysis sustainability of the southern region of west Java development using RAP-Region-Dev

In the ecological dimension, the most sensitive attribute to sustainability is the "geographically proximate to water resources", as well as the poor water quality in almost all of these districts which have always been the main problem for the development of the region. The 
groundwater, as well as the surface water, like the stream and water spring, are the community's source of drinking water, which are hard to maintain during the dry season because, in addition to wide illegal logging and settlement start-up by the upstream that the catchment area is reduced, the domestic waste dumped into the river also pollutes the river. On the economic dimension, the most sensitive to determine sustainability is the income and WTP (Willingness to Pay) of the community towards the development of the southern region of west Java. A high WTP of a community reflects the high public appraisal of the region, which means that the community understands the true significance of the region either tangible or intangible. This is the basis for the society to have a sense of belonging and to manage the future of this region, even though the main economic issue in the community of the local region is poverty, as seen in other sensitive attributes.

On the social attribute, the determinant of sustainability is the crime rate and corporate social responsibility (CSR). The condition due to the high crime rate will disturb social sustainability. Also, so long as there is CSR, the community capacity can be improved to start a business based on their interest and expertise, other than their usually resource-related works based economy they used to live with.

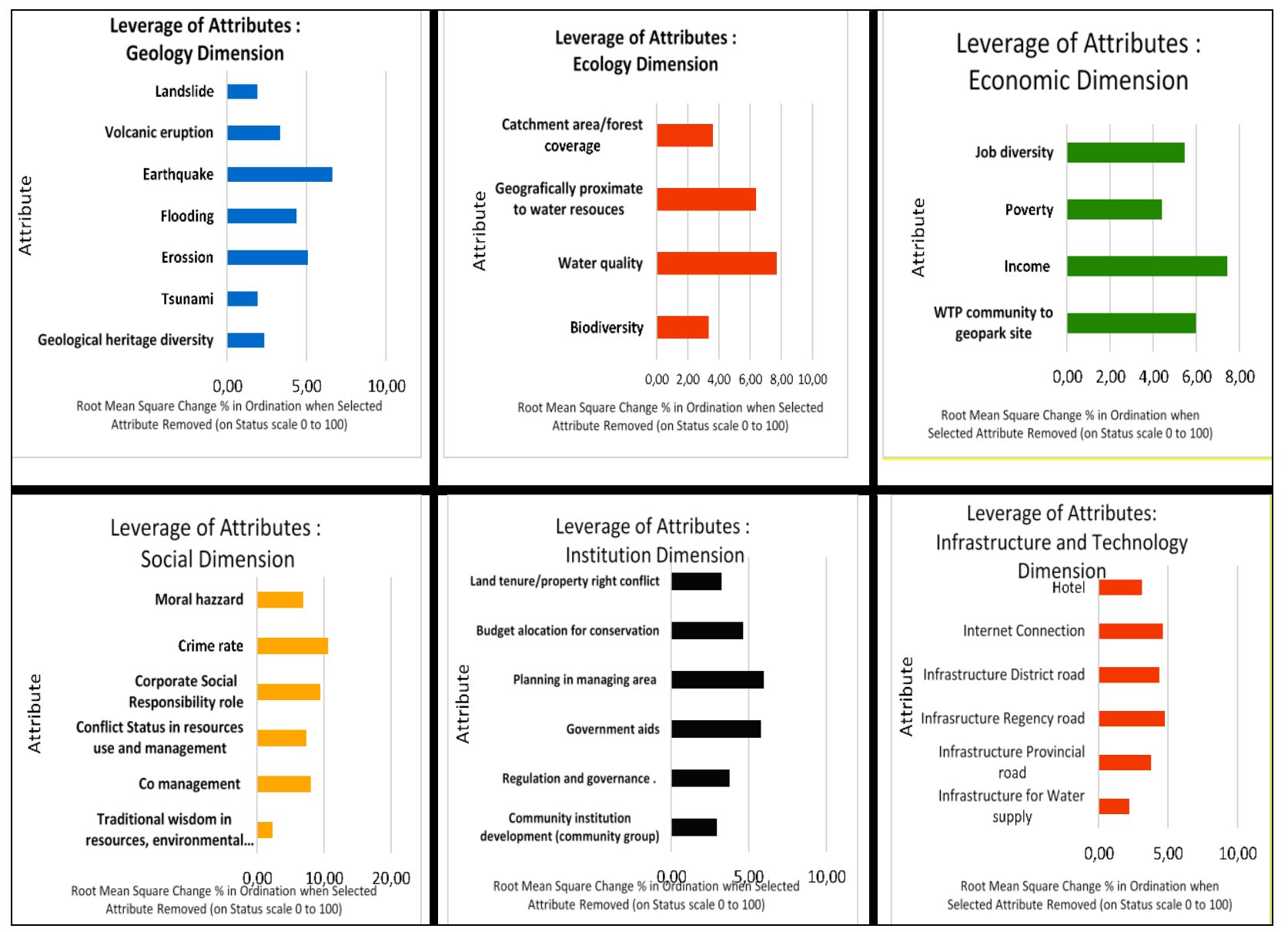

Figure 6. Sustainability leverage on each dimension

As for institution attribute, planning, and area management, the government's aid and budget for conservation are the keys to the sustainability of development in the southern region of west Java. We know that the planning is feeble, as well as the government's aid and the budget allocation for conservation. This condition determines whether the southern region of west Java will last or not. Meanwhile, on the infrastructure or technology dimension, the regency and district road infrastructure and the internet connection become key attributes that determine the sustainability of the southern region of west Java development onward. The tourism sector will attract a lot of visitors, and the road will become a necessity for the ease of access, as well as the Internet that is a necessity in the current global era.

Strong support by Law No. 2/2015 in the management of the southern region of West Java so that it can more clearly be identified to resolve social conflicts (both potential and actual). West Java Provincial Government had become increasingly concerned about the detrimental impact of sea sand mining on important fisheries resources, and within the district government and other government agencies, strongly supported the ban on sea sand mining in coastal areas of West Java. University scholars examining the impact of sea sand mining on small-scale fishing communities documented serious declines in income, the reduction of employment opportunities within the fisheries sector, and the general marginalization of small-scale fisheries within that sector. Popular awareness of widespread unrest among fishermen was established through the print media. Reporters actively publicized the plight of small-scale fishermen. Several influential politicians working through the "All-Indonesia Fishermen's Association" (Himpunan Nelayan Se-Indonesia, or HNSI) also became effective lobbyists in support of small-scale fishermen's traditional resource use rights, arguing that sea sand miner operations should be curtailed or eliminated.

The HNSI is a nominally non-governmental organization representing the interests of small-scale fishermen. In practice, the HNSI serves as a forum through which small-scale fishermen can communicate their concerns to the government. As such, it fits a general pattern of the socio-political organization under the government of Indonesia administration whereby various interests are aggregated into identifiable "functional groups." These groups serve to articulate interests in the government and provide a power base to politicians. Governmental responsiveness to the needs of these groups and their leaders, in turn, serves to build and maintain political support. Thus, groups such as the HNSI have influence in government councils because they generally support the government. Politicians closely associated with the government tend to be selected as leaders of such groups, as is the case with the HNSI, to provide assured access to the corridors of power. In return, these politicians have assured an organized constituency in a political system without direct national elections. 
One further factor, the issue of ethnicity, must be mentioned if we are to explain the government's decisions to ban sea sand miners. Most of the owners of sea sand miners were Indonesian citizens of Chinese descent. Ethnic Chinese comprise roughly $3 \%$ of the national population but dominate key sectors of Indonesia's economy, just as they do throughout Southeast Asia. Among all citizens, they are the ones most likely to have access to the capital resources necessary to invest in sea sand miners or any other profitable enterprise.

Most small-scale fishermen, however, are not ethnic Chinese but rather Javanese, Sudanese, Malay, or other indigenous ethnic groups are known collectively as pribumi (indigenous people). There is a long history of ethnic antagonism between the economically aggressive Chinese and the indigenous populations of Indonesia.

On the other hand, the legal right to use natural resources changes the principle of open access for the community to geographical resources. Based on Java's social law, in the context of the southern region of West Java, these rights are related to indigenous groups and NGOs as groups that have management permits, so that a system of joint property sustainability will exist (Ruddle and Johannes, 1985). Use of usage rights by indigenous groups and NGOs as their concept can be applied to a variety of circumstances and provides an ethical basis for supporting access to natural resources in the southern region of West Java. Whether these rights are a determining factor in determining natural resource development and management policies must be determined on a case-by-case basis by those responsible for making decisions. The prohibition of mining sea sand in the southern region of West Java is a good example of the type of management that will determine the compilation of traditional community resource use rights (Sumaatmadja, 2012).

The existence or absence of property rights over the resource itself is a matter of fundamental importance in conceptualizing these policy issues. In natural resource exploiting, problems of over-exploitation generally are attributed to the lack of clear property rights and the consequent efforts of stakeholders to maximize benefits even at the expense of resource sustainability and long-term societal good (Gordon, 1954; Rizal, 2018b). The temptations for personal profit entailed in the historical process described above would have placed tremendous internal pressure on common property resource systems in West Java. Consolidation of power by the provincial government, and the expanded presence of district government in areas of the southern of West Java, may have undermined the authority of local institutions responsible for common property resource management.

\section{CONCLUSION}

The southern region of west Java development requires careful and integrated planning in a relatively complex and difficult process. Having geological resources potentials alone does not determine the development of the area into the southern region of west Java that is particularly a tourism economic activity and the conservation of the geological resources and biodiversity that generally inhabit the region.

A sustainable the southern region of west Java development begins with a scientifically based understanding of integrated geology like structural geology/engineering, fluency in rocks, geological hazards, and environmental geology. Moreover, the southern region of west Java development is inseparable from the development of the utilization of biological diversity and culture as an attraction, thus the understanding of both is very necessary.

The southern region of west Java development should be done involving all of the elements in the society that is the government, the community, the academia, the private sector, and other non-governmental organizations, locally, nationally and globally (inclusive) because, without all of them, the planning and management will not run optimally. Community empowerment is also a key to the development of the southern region of west Java, given that the education and economy are still inadequate. To trigger the region's economyis one of the goals of the southern regon of west Java development, thus the involvement of the government and the private sector, needs to be pushed on.

The readiness site and the analysis of the southern region of west Java-development sustainability (Rap-Region-dev) are tools to understand the readiness for the southern region of west Java development sustainability onward. This paper described how the readiness analysis could direct the managers and the stakeholders involved to improve and manage the indicators that were considered not ready, whether it concerns on background information, potential stakeholders, institutional aspects, or any possible impact. The condition of the southern region of west Java shows how some aspects, of which they include the most fundamental aspect that is the background information, still need a lot of research that can be conducted through collaborations with academia and research institutes.

Moreover, with the institutional development that is as well as important considering the regional regulations, proper planning, and design development framework will drive the investment that will be the trigger for the southern region of west Java development. On the other hand, the southern region of west Java development impacts that started to show at the beginning of the development of the existing conditionis the economic, social, and environmental impacts are necessary to watch over and considered as the foundation of decisionmaking for the readiness of the southern region of west Java development. Cases in the southern region of west Java show how negative social impact already made itself known, even at this early stage of the southern region of west Java development.

Rap-Region-dev analyses are also a tool to detect the development sustainability of the southern region of west Java. Using several dimensions and attributes, it can be seen to what extent each of these dimensions and attributes will carry the southern region of west Java onward. For example, it appears that each subdistrict analyzed had a sustainability level in correlation to various dimensions and attributes. There is a possibility to consider any specific sub-region with a low sustainability level in all dimensions too for an exclusion from the plan area (boundaries) of the southern region of west Java. It may happen due to the lack of carrying capacity and good assimilation capacity in the region, or it may not have sufficient supporting resources, or perhaps because of a high potential hazard.

This study contributes to the ideas, especially in incorporating socio-economic and environmental variables in the southern region of west Java development. Emphasized understanding of the intangible value of the area throughthe analysis of the Willingness to Pay (WTP) of the people who express their will to sacrifice some money for the development of southern region of west Java reflects the intangible value of the region, which may be of use later as the entrance fee pricing for this region.

\section{Aknowlegments}

The authors wish to thank Universitas Padjadjaran, which funded the study through internal research grant year 2020 budget based on contract number: $1427 /$ UN6.3.1 /LT/2020.

\section{REFERENCES}

Afroz, R., Masud, M.M., Akhtar, R., \& Duasa, J.B. (2014). Water pollution: Challenges and future direction for water resource management policies in Malaysia. Environment and urbanization ASIA, 5(1), 63-81.

Armitage, D., de Loë, R.C., Morris, M., Edwards, T.W., Gerlak, A.K., Hall, R.I., ... \& Mirumachi, N. (2015). Science-policy processes for transboundary water governance. Ambio, 44(5), 353-366.

Aswita, D., Suryadarma, I.G.P., \& Suyanto, S. (2018). Local Wisdom of Sabang Island Society (Aceh, Indonesia) in Building Ecological Intelligence to Support Sustainable Tourism. GeoJournal of Tourism and Geosites, 22(2), 393-402. 
Bakosurtanal (2014). The rainfall map of Indonesia, National Coordinating Agency for Surveys and Mapping, Bogor, Indonesia.

Boley, B.B., \& Nickerson, N.P. (2013). Profiling geotravelers: an a priori segmentation identifying and defining sustainable travelers using the Geotraveler Tendency Scale (GTS). Journal of Sustainable Tourism, 21(2), 314-330.

Central Statistics Bureau (2018). West Java Province in Figures. Central Statistics Bureau of West Java Province. Indonesia.

Chen, Q., Liu, Y.Y., Xue, C., Yang, Y.L., \& Zhang, W.M. (2015). Energy self-sufficient desalination stack as a potential fresh water supply on small islands. Desalination, 359, 52-58.

Daily, C.M., Dalton, D.R., \& Cannella Jr, A.A. (2003). Corporate governance: Decades of dialogue and data. Academy of management review, $28(3)$, 371-382.

De Stefano, L., Svendsen, M., Giordano, M., Steel, B.S., Brown, B., \& Wolf, A.T. (2014). Water governance benchmarking: concepts and approach framework as applied to Middle East and North Africa countries. Water Policy, 16(6), 1121-1139.

Department ofenergy and mineral resourcesof West Java Province (2014). Inventory and identification of Karst regions in West Java-Indonesia, unpublished. http://esdm.jabarprov.go.id/profil-dinas-esdm/report.

Department of energy and mineral resources ofWest Java Province (2017). Final report on planning and determination of geological nature reserves in West Java, unpublished. http://esdm.jabarprov.go.id/profil-dinas-esdm/report

Dominick, D., Latif, M.T., Juahir, H., Aris, A.Z., \& Zain, S.M. (2012). An assessment of influence of meteorological factors on PM sub (10) and NO sub (2) at selected stations in Malaysia. Sustainable Environment Research, 22(5), 305-315.

Duda, A.M., \& Hume, A.C. (2013). A new imperative to harness sound science in the GEF international waters focal area. Environmental Development, $7,102-108$.

Fauzi, A., \& Anna, S. (2002). Sustainability status evaluation of fisheries development: rapfish aplication (case study dki jakarta coastal waters). Coastal and Marine Resources, 3(4), 43-55.

Fauzi, A., \& Anna, S. (2005). Fisheries and marine resources modelling for policy analysis, Gramedia Pustaka Utama, Jakarta.

Franks T., \& Cleaver F. (2007). Water governance and poverty: a framework for analysis. Progress in Development Studies. Vol 7(4):291-306.

Freeze, R.A. (1979). Groundwater, Printice-Hall Inc., New Jersey.

Gordon, H.S. (1954). The economic theory of a common-property resource: the fishery. Journal of Political Economy, 62, 124-42.

Hakim, L., \& Soemarno, M. (2017). Biodiversity Conservation, Community Development and Geotourism Development in Bromo-Tengger-Semeru-Arjuno Biosphere Reserve, East Java. GeoJournal of Tourism and Geosites, 20(2), 220-230.

Indonesian Presidential Decree (2011). Presidential decree No. 26 of 2011 about Thedetermination of groundwater basin, Indonesia.

Khajegan, M.,Vagharfard, H., \& Shahdadi, K.A. (2015). Evaluating geopark potentials in tourism development in qeshm island with an emphasis on ecotourism usingSWOT Method. In Jam J Sci Tech., 26, 1-16.

Kodir, A. (2018). Tourism and Development: Land Acquisition, Achievement of Investment and Cultural Change (Case Study Tourism Industry Development in Batu City, Indonesia). GeoJournal of Tourism and Geosites, 21(1), 253-265.

Lave, R. (2012). Fields and streams: Stream restoration, neoliberalism, and the future of environmental science, University of Georgia Press.

Law No. 2 of 2015 concerning Regional Government. Ministry of Law and Regulations of the Republic of Indonesia.

Lindegard, S. (2010). The open inovation revolution: essentials, roadblocks and leadership skills, John Wiley \& Sons.

Mekonnen, M.M., \& Hoekstra, A.Y. (2016). Four billion people facing severe water scarcity. Science advances, $2(2)$, e1500323.

Ministry of Energy and Mineral Resources (2014). Regulation regarding mining zones in Java and Bali island in Act No. 1204 K/30/MEM/2014. Goverment of Republic Indonesia.

Pahl-Wostl, C., Conca, K., Kramer, A., Maestu, J., \& Schmidt, F. (2013). Missing links in global water governance: a processes-oriented analysis. Ecology and Society, 18(2), 122-130.

Palmer, M.A. (2012). Socioenvironmental sustainability and actionable science. BioScience, 62(1), 5-12.

Pitcher, T.J., \& Preikshot, D. (2001). RAPFISH: a rapid appraisal technique to evaluate the sustainability status of fisheries. Fisheries Research, $49(3), 255-270$.

Pitcher, T.J. (1999). Rapfish, a rapid appraisal technique for fisheries, and its application to the Code of Conduct for Responsible Fisheries. FAO Fisheries Circular (FAO).

Pitcher, T.J., Lam, M.E., Ainsworth, C., Martindale, A., Nakamura, K., Perry, R.I., \& Ward, T. (2013). Improvements to Rapfish: a rapid evaluation technique for fisheries integrating ecological and human dimensionsa. Journal of Fish Biology, 83(4), 865-889. doi:10.1111/jfb.12122.

Rizal, A., \& Dewanti, L.P. (2017). Using economic values to evaluate management options for fish biodiversity in the Sikakap Strait, Indonesia. Biodiversitas Journal of Biological Diversity, 18(2), 575-581.

Rizal, A., Juahir, H., \& Lananan, F. (2019). Freshwater Governance on Limboto Lake in Gorontalo Province of Indonesia. Indian Journal of Public Health Research \& Development, 10(4), 782-787.

Rizal, A. (2018a). Reformulation of Regional Development Strategy To Strengthen Marine Sector in West Java, Indonesia. World Scientific News, $107,207-215$.

Rizal, A. (2018b). Science and policy in the coastal zone management. World News of Natural Sciences, 21, 1-8.

Rosana, M.F., Budiman, D., Herry, Hardiyono, A., \& Yanuar, Y. (2015). Preparation to become national geopark \& GGN member: case study Ciletuh Geopark, West Java, Indonesia. $4^{\text {th }}$ Asia Pacific Geopark Network, San in Kaigan Symposium, Tottori, Japan.

Rosana, M.F., Undang, M., Ildrem, S., Nana, S., \& Iyan, H. (2006). Geological Area Ciletuh, Sukabumi: characteristics, uniqueness and implications, Presented at "Lokakarya Penelitian Unggulan dan Pengembangan Program Pascasarjana”, FMIPA- Universitas Padjadjaran.

Ruddle, K., \& Johannes, R.E. (eds.). (1985). The traditional knowledge and management of coastal systems in Asia and the Pacific. Jakarta: UNESCO, Regional Office for Science and Technology for Southeast Asia.

Spatial planning of west Java province (SPWP). (2010). West Java regional regulation no. 22 of 2010 about spatial planning for West Java Province Year 2009-2029, Indonesia.

Sumaatmadja, N. (2012). Humans in Social, Cultural and Environmental Contexts. Bandung: Alfabeta.

Sutrisno (1985). Map of Sukabumi sheet hydrogeology map, Directorate of Environmental Geology, Department of Energy and Mineral Resources, Indonesia.

Turner, S. (2006). Promoting UNESCO Global Geoparks for sustainable development in the Australian-Pacific region. Alcheringa: An Australasian Journal of Palaeontology, 30(S1), 351-365.

UN-General Assembly (2015). Transforming Our World. The 2030 Agenda for Sustainable Development.

UN-Water (2015). Water for a sustainable world. The United Nations World Water Development Report. DOI: 10.1016/S1366-7017 (02) 00004-1.

West Java Province Regional Regulation Number 22 (2010). Concerning Spatial Planning for West Java Province Year 2009-2029. West Java Province Planning and Development Agency. Indonesia

Wilk, E.O., \& Fensterseiler, J. (2003). Use of resource-based view in industrial cluster strategic analysis. International Journal of Operations \& Production Management, 31(9), 995-1009, https://doi.org/10.1108/01443570310491747.

Woodley, E. (2002). Local and indigenous knowledge as an emergent property of complexity: A case study in the Solomon Islands, University of Guelph.

Wunder, S. (2000). Ecotourism and economic incentives-an empirical approach. Ecological economics, 32(3), 465-479.

*** Regulations of West Java Governor (2006). Regional Karst Protection of West Java on No. 20/2006. West Java Province Planning and Development Agency. Indonesia.

*** World Bank, (2006), Poverty and social impact analysis: participatory tools for micro-level poverty and social impact analysis. 